\title{
Factors in the Emergence of Infectious Diseases
}

\author{
Stephen S. Morse, Ph.D. \\ The Rockefeller University, New York, NewYork, USA
}

\begin{abstract}
"Emerging" infectious diseases can be defined as infections that have newly appeared in a population or have existed but are rapidly increasing in incidence or geographic range. Among recent examples are HIV/ AIDS, hantavirus pulmonary syndrome, Lyme disease, and hemolytic uremic syndrome (a foodborne infection caused by certain strains of Escherichia coli). Specific factors precipitating disease emergence can be identified in virtually all cases. These include ecological, environmental, or demographic factors that place people at increased contact with a pre viously unfamiliar microbe or its natural host or promote dissemination. These factors areincreasing in preval ence, this increase, together with theongoing evolution of viral and microbial variants and selection for drug resistance, suggests that infections will continue to emerge and probably increase and emphasizes the urgent need for effective surveillance and control. Dr. David Satcher's article and this overview inaugurate "Perspectives," a regular section in this journal intended to present and develop unifying concepts and strategies for considering emerging infections and their underlying factors. The editors wel come, as contributions to the Perspectives section, overviews, syntheses, and case studies that shed light on how and why infections emerge, and how they may be anticipated and prevented.
\end{abstract}

Infectious diseases emerging throughout history have included some of the most feared plagues of the past. New infections continue to emerge today, while many of the old plagues are with us still. These are global problems (William Foege, former CDC director now at the Carter Center, terms them "global infectious disease threats"). As demonstrated by influenza epidemics, under suitable circumstances, a new infection first appearing anywhere in the world could traverse entire continents within days or weeks.

We can define as "emerging" infections that have newly appeared in the population, or have existed but are rapidly increasing in incidence or geographic range $(1,2)$. Recent examples of emerging diseases in various parts of the world include HIVIAIDS; classic cholera in South Ameri ca and Africa; cholera due to Vibrio cholerae O139; Rift Valley fever; hantavirus pulmonary syndrome; Lyme disease; and hemolytic uremic syndrome, a foodborne infection caused by certain strains of Escherichia coli (in the United States, serotype O157:H7).

Although these occurrences may appear inexplicable, rarely if ever do emerging infections appear without reason. Specific factors responsible for disease emergence can be identified in virtually all cases studied (2-4). Table 1 summarizes the known

Address for correspondence: Stephen S. Morse, The Rockefeller University, 1230 York Avenue, Box 120, New York, NY 10021-6399, USA; fax 212-327-7172; e-mail morse@rockvax.rockefeller.edu. causes for a number of infections that have emerged recently. I have suggested that infectious disease emergencecan beviewed operationally as a two-step process: 1) I ntroduction of the agent into a new host population (whether the pathogen originated in the environment, possibly in another species, or as a variant of an existing human infection), followed by 2) establishment and further dissemination within the new host population ("adoption") (4). Whatever its origin, the infection "emerges" when it reaches a new population. Factors that promote one or both of these steps will, therefore, tend to precipitate disease emergence. Most emerging infections, and even antibiotic-resistant strains of common bacterial pathogens, usually origi natein one geographic location and then disseminate to new places (5).

Regarding the introduction step, the numerous examples of infections originating as zoonoses $(7,8)$ suggest that the "zoonotic pool"-introductions of infections from other species-is an important and potentially rich source of emerging diseases; periodic discoveries of "new" zoonoses suggest that the zoonotic pool appears by no means exhausted. Once introduced, an infection might then bedisseminated through other factors, although rapid course and high mortality combined with low transmissibility are often limiting. However, even if a zoonotic agent is not able to spread readily from person to person and establish itself, other factors (e.g., nosocomial infection) might transmit theinfection. Additionally, if the reservoir host or vector becomes more widely disseminated, themicrobecan appear in new places. 


\section{Perspectives}

Table 1. Recent examples of emerging infections and probable factors in their emergence

\begin{tabular}{|c|c|}
\hline Infection or Agent & Factor(s) contributing to emergence \\
\hline \multicolumn{2}{|l|}{ Viral } \\
\hline $\begin{array}{l}\text { Argentine, Bolivian hemorrhagic } \\
\text { fever }\end{array}$ & Changes in agriculture favoring rodent host \\
\hline $\begin{array}{l}\text { Bovine spongiform } \\
\text { encephalopathy (cattle) }\end{array}$ & Changes in rendering processes \\
\hline Dengue, dengue hemorrhagic fever & Transportation, travel, and migration; urbanization \\
\hline Ebola, Marburg & Unknown (in Europe and the United States, importation of monkeys) \\
\hline Hantaviruses & Ecological or environmental changes increasing contact with rodent hosts \\
\hline Hepatitis B, C & $\begin{array}{l}\text { Transfusions, organ transplants, contaminated hypodermic apparatus, } \\
\text { sexual transmission, vertical spread from infected mother to child }\end{array}$ \\
\hline HIV & $\begin{array}{l}\text { Migration to cities and travel; after introduction, sexual transmission, } \\
\text { vertical spread from infected mother to child, contaminated hypodermic } \\
\text { apparatus (induding during intravenous drug use), transfusions, organ } \\
\text { transplants }\end{array}$ \\
\hline HTLV & Contaminated hypodermic apparatus, other \\
\hline Influenza (pandemic) & $\begin{array}{l}\text { Possibly pig-duck agriculture, facilitating reassortment of avian and } \\
\text { mammalian influenza viruses* }\end{array}$ \\
\hline Lassa fever & Urbanization favoring rodent host, increasing exposure (usually in homes) \\
\hline Rift Valley fever & $\begin{array}{l}\text { Dam building, agriculture, irrigation; possibly change in virulence or } \\
\text { pathogenicity of virus }\end{array}$ \\
\hline Yellow fever (in "new" areas) & Conditions favoring mosquito vector \\
\hline \multicolumn{2}{|l|}{ Bacterial } \\
\hline $\begin{array}{l}\text { Brazilian purpuric fever } \\
\text { (Haemophilus influenzae, } \\
\text { biotype aegyptius) }\end{array}$ & Probably new strain \\
\hline Cholera & $\begin{array}{l}\text { In recent epidemic in South America, probably introduced from Asia by ship, } \\
\text { with spread facilitated by reduced water chlorination; a new strain (type } \\
\text { O139) from Asia recently disseminated by travel (similarly to past } \\
\text { introductions of classic cholera) }\end{array}$ \\
\hline Helicobacter pylori & $\begin{array}{l}\text { Probably long widespread, now recognized (associated with gastric ulcers, } \\
\text { possibly other gastrointestinal di sease) }\end{array}$ \\
\hline $\begin{array}{l}\text { Hemolytic uremic syndrome } \\
\text { (Escherichia coli O157:H7) }\end{array}$ & Mass food processing technology allowing contamination of meat \\
\hline Legionela (Legionnaires' disease) & $\begin{array}{l}\text { Cooling and plumbing systems (organism grows in biofilms that form on } \\
\text { water storage tanks and in stagnant plumbing) }\end{array}$ \\
\hline $\begin{array}{l}\text { Lyme borreliosis (Borrelia } \\
\text { burgdorferi) }\end{array}$ & $\begin{array}{l}\text { Reforestation around homes and other conditions favoring tick vector and } \\
\text { deer (a secondary reservoir host) }\end{array}$ \\
\hline $\begin{array}{l}\text { Streptococcus, group A (invasive; } \\
\text { necrotizing) }\end{array}$ & Uncertain \\
\hline $\begin{array}{l}\text { Toxic shock syndrome } \\
\text { (Staphylococcus aureus) }\end{array}$ & Ultra-absorbency tampons \\
\hline \multicolumn{2}{|l|}{ Parasitic } \\
\hline $\begin{array}{l}\text { Cryptosporidium, other } \\
\text { waterborne pathogens }\end{array}$ & Contaminated surface water, faulty water purification \\
\hline Malaria (in “new” areas) & Travel or migration \\
\hline Schistosomiasis & Dam building \\
\hline
\end{tabular}

* Reappearances of influenza are due to two distinct mechanisms: Annual or biennial epidemics involving new variants due to antigenic drift (point mutations, primarily in the gene for the surface protein, hemagglutinin) and pandemic strains, arising from antigenic shift (genetic reassortment, generally between avian and mammalian influenza strains). 


\section{Perspectives}

Bubonic plague transmitted by rodent fleas and ratborne hantavirus infections are examples.

Most emerging infections appear to be caused by pathogens already present in the environment, brought out of obscurity or given a selective advantage by changing conditions and afforded an opportunity to infect new host populations (on rare occasions, a new variant may also evolve and cause a new disease) $(2,4)$. The process by which infectious agents may transfer from animals to humans or disseminate from isolated groups into new populations can becalled "mi crobial traffic" $(3,4)$. A number of activities increase mi crobial traffic and as a result promote emergence and epidemics. In some cases, including many of the most novel infections, the agents are zoonotic, crossing from their natural hosts into the human population; because of the many similarities, I include here vector-borne diseases. In other cases, pathogens al ready present in geographically isolated populations are given an opportunity to disseminate further. Surprisingly often, disease emergence is caused by human actions, however inadvertently; natural causes, such as changes in climate, can al so at times be responsible (6). Although this discussion is confined largely to human disease, similar considerations apply to emerging pathogens in other species.

Table 2 summarizes the underlying factors re sponsible for emergence. Any categorization of the factors is, of course, somewhat arbitrary but should be representative of the underlying processes that cause emergence. I have essentially adopted the categories developed in the Institute of Medicine report on emerging infections (12), with additional definitions from the CDC emerging infections plan (13). Responsible factors ind ude ecological changes, such as those due to agricultural or economic development or to anomalies in climate; human demographic changes and behavior; travel and commerce; technology and industry; mi crobial adaptation and change; and breakdown of public health measures. Each of these will be considered in turn.

E col ogical interactions can be complex, with several factors often working together or in sequence. F or example, population movement from rural areas to cities can spread a once-localized infection. The strain on infrastructure in the overcrowded and rapidly growing cities may disrupt or slow public health measures, perhaps allowing establishment of the newly introduced infection. Finally, the city may also provide a gateway for further dissemination of the infection. Most successful emerging infections, including HIV, cholera, and dengue, have followed this route.

Consider HIV as an example. Although the precise ancestry of HIV-1 is still uncertain, it appears to have had a zoonotic origin $(9,10)$. E cological factors that would have allowed human exposure to a natural host carrying the virus that was the precursor to HIV-1 were, therefore, instrumental in the introduction of the virus into humans. This probably occurred in a rural area. A plausible scenario is suggested by the identification of an HIV-2-infected man in a rural area of Liberia whose virus strain resembled viruses isol ated from the sooty mangabey monkey (an animal widely hunted for food in rural areas and the putative source of HIV-2) more closely than it did strains circulating in the city (11). Such findings suggest that zoonotic introductions of this sort may occur on occasion in isolated populations but may well go unnoticed so long as the recipients remain isolated. But with increasing movement from rural areas to cities, such isolation is increasingly rare. After its likely first move from a rural area into a city, HIV-1 spread regionally along highways, then by long distance routes, including air travel, to more distant places. This last step was critical for HIV and facilitated today's global pandemic. Social changes that all owed the virusto reach a larger population and to be transmitted despiteits relatively low natural transmissibility were instrumental in the success of the virus in its newfound human host. For HIV, thelong duration of infectivity allowed this normally poorly transmissible virus many opportunities to be transmitted and to take advantage of such factors as human behavior (sexual transmission, intravenous drug use) and changing technology (early spread through blood transfusions and blood products) (Table 1).

\section{Ecological Changes and Agricultural Development}

Ecological changes, including those due to agricultural or economic development, are among the most frequently identified factors in emergence. They are especially frequent as factors in outbreaks of previously unrecognized diseases with high casefatality rates, which often turn out to be zoonotic introductions. E cological factors usually precipitate emergence by placing people in contact with a natural reservoir or host for an infection hitherto unfamiliar but usually al ready present (often a zoonotic or arthropod-borne infection), either by increasing proximity or, often, also by changing conditions so as to favor an increased population of the mi crobe or its natural host $(2,4)$. The emergence of Lyme disease in the United States and Europe was probably duelargely toreforestation (14), which increased the population of deer and the deer tick, the vector of Lyme disease. The movement of people into these areas placed a larger population in close proximity to the vector.

Agricultural development, one of the most common ways in which people alter and interposethemselves into the environment, is often a factor 


\section{Perspectives}

Table 2. Factors in infectious disease emergence*

\begin{tabular}{|c|c|c|}
\hline Factor & Examples of specific factors & Examples of diseases \\
\hline $\begin{array}{l}\text { Ecological changes (including } \\
\text { those due to economic } \\
\text { development and land use) }\end{array}$ & $\begin{array}{l}\text { Agriculture; dams, changes in } \\
\text { water ecosystems; } \\
\text { defor estation/reforestation; } \\
\text { flood/drought; famine; dimate } \\
\text { changes }\end{array}$ & $\begin{array}{l}\text { Schistosomiasis (dams); Rift Valley fever } \\
\text { (dams, irrigation); Argentine hemorrhagic } \\
\text { fever (agriculture); Hantaan (Korean } \\
\text { hemorrhagic fever) (agri culture); } \\
\text { hantavirus pulmonary syndrome, } \\
\text { southwestern US, } 1993 \text { (weather } \\
\text { anomalies) }\end{array}$ \\
\hline $\begin{array}{l}\text { Human demographics, } \\
\text { behavior }\end{array}$ & $\begin{array}{l}\text { Societal events: Population } \\
\text { growth and migration } \\
\text { (movement from rural areas } \\
\text { to cities); war or civil conflict; } \\
\text { urban decay; sexual behavior; } \\
\text { intravenous drug use; use of } \\
\text { high-density facilities }\end{array}$ & $\begin{array}{l}\text { Introduction of HIV; spread of dengue; spread } \\
\text { of HIV and other sexually transmitted } \\
\text { diseases }\end{array}$ \\
\hline $\begin{array}{l}\text { International travel and } \\
\text { commerce }\end{array}$ & $\begin{array}{l}\text { Worldwide movement of goods } \\
\text { and people; air travel }\end{array}$ & $\begin{array}{l}\text { "Airport" malaria; dissemination of mosquito } \\
\text { vectors; ratborne hantaviruses; } \\
\text { introduction of cholera into South America; } \\
\text { dissemination of O139 V. cholerae }\end{array}$ \\
\hline Technology and industry & $\begin{array}{l}\text { Globalization of food supplies; } \\
\text { changes in food processing } \\
\text { and packaging; organ or } \\
\text { tissue transplantation; drugs } \\
\text { causing immunosuppression; } \\
\text { widespread use of antibiotics }\end{array}$ & $\begin{array}{l}\text { Hemolytic uremic syndrome (E. col i } \\
\text { contamination of hamburger meat), bovine } \\
\text { spongiform encephal opathy; } \\
\text { transfusion-associated hepatitis (hepatitis } \\
\text { B, C), opportuni stic infections in } \\
\text { immunosuppressed patients, } \\
\text { Creutzfel dt-J akob disease from } \\
\text { contaminated batches of human growth } \\
\text { hormone (medical technology) }\end{array}$ \\
\hline $\begin{array}{l}\text { Microbial adaptation and } \\
\text { change }\end{array}$ & $\begin{array}{l}\text { Microbial evolution, response to } \\
\text { selection in environment }\end{array}$ & $\begin{array}{l}\text { Antibiotic-resistant bacteria, "antigeni c drift" } \\
\text { in influenza virus }\end{array}$ \\
\hline $\begin{array}{l}\text { Breakdown in public health } \\
\text { measures }\end{array}$ & $\begin{array}{l}\text { Curtailment or reduction in } \\
\text { prevention programs; } \\
\text { inadequate sanitation and } \\
\text { vector control measures }\end{array}$ & $\begin{array}{l}\text { Resurgence of tuberculosis in the United } \\
\text { States; cholera in refugee camps in Africa; } \\
\text { resurgence of diphtheria in the former } \\
\text { Soviet Union }\end{array}$ \\
\hline
\end{tabular}

* Categories of factors (column 1) adapted from ref. 12, examples of specific factors (column 2) adapted from ref. 13. Categories are not mutually exdusive; several factors may contribute to emergence of a disease (see Table 1 for additional information).

(Table 2). Hantaan virus, the cause of Korean hemorrhagic fever, causes over 100,000 cases a year in China and has been known in Asia for centuries. The virus is a natural infection of the field mouseApode mus agrarius. The rodent flourishes in rice fields; people usually contract the disease during the rice harvest from contact with infected rodents. J unin virus, the cause of Argentine hemorrhagic fever, is an unrelated virus with a history remarkably si miIar to that of Hantaan virus. Conversion of grassland to maize cultivation favored a rodent that was the natural host for this virus, and human cases increased in proportion with expansion of maize agriculture (15). Other examples, in addition to those already known $(2,15)$, are likely to appear as new areas are placed under cultivation.
Perhaps most surprisingly, pandemic influenza appears to have an agricultural origin, integrated pig-duck farming in China. Strains causing the frequent annual or biennial epidemics generally result from mutation ("antigenic drift"), but pandemic influenza viruses do not generally arise by this process. Instead, gene segments from two influenza strains reassort to produce a new virus that can infect humans (16). Evidence amassed by Webster, Scholtissek, and others, indicates that waterfowl, such as ducks, are major reservoirs of influenza and that pigs can serve as "mixing vessels" for new mammalian influenza strains (16). Pandemi c influenza viruses have generally come from China. Scholtissek and Naylor suggested that integrated pig-duck agriculture, an extremely efficient food 


\section{Perspectives}

production system traditionally practiced in certain parts of China for several centuries, puts these two species in contact and provides a natural laboratory for making new influenza recombinants (17). Webster has suggested that, with high-intensity agriculture and movement of livestock across borders, suitableconditions may now also be found in Europe (16).

Water is also frequently associated with disease emergence. I nfections transmitted by mosquitoes or other arthropods, which indude some of the most serious and widespread diseases $(18,19)$, are often stimulated by expansion of standing water, simply because many of the mosquito vectors breed in water. Thereare many cases of di seases transmitted by water-breeding vectors, most involving dams, water for irrigation, or stored drinking water in cities. (See "Changes in Human Demographics and Behavior" for a di scussion of dengue.) The incidence of J apanese encephalitis, another mosquito-borne disease that accounts for almost 30,000 human cases and approximately 7,000 deaths annually in Asia, is closely associated with flooding of fields for rice growing. Outbreaks of Rift Valley fever in some parts of Africa have been associated with dam building as well as with periods of heavy rainfall (19). In the outbreaks of Rift Valley fever in Mauritania in 1987, the human cases occurred in villages near dams on the Senegal River. The same effect has been documented with other infections that have aquatic hosts, such as schistosomiasis.

Because humans are important agents of ecological and environmental change, many of thesefactors are anthropogenic. Of course, this is not al ways the case, and natural environmental changes, such as climate or weather anomalies, can have the same effect. The outbreak of hantavi rus pulmonary syndrome in the southwestern United States in 1993 is an example. It is likely that the virus has long been present in mouse populations but an unusually mild and wet winter and spring in that area led to an increased rodent population in the spring and summer and thus to greater opportunities for people to come in contact with infected rodents (and, hence, with the virus); it has been suggested that the weather anomaly was due to large-scale dimatic effects (20). The same causes may have been responsible for outbreaks of hantaviral disease in Europe at approximately the same time $(21,22)$. With cholera, it has been suggested that certain organisms in marine environments are natural reservoirs for cholera vibrios, and that large scal e effects on ocean currents may cause local increases in the reservoi $r$ organism with consequent flare-ups of cholera (23).

\section{Changes in Human Demographics and Behavior}

Human population movements or upheavals, caused by migration or war, are often important factors in disease emergence. In many parts of the world, economic conditions are encouraging the mass movement of workers from rural areas to cities. The United Nations has estimated that, largely as a result of continuing migration, by theyear 2025, $65 \%$ of the world population (also expected to be larger in absolute numbers), including $61 \%$ of the population in developing regions, will live in cities (24). As discussed above for HIV, rural urbanization allows infections arising in isolated rural areas, which may once have remained obscure and localized, to reach larger populations. Once in a city, the newly introduced infection would have the opportunity to spread locally among the population and could also spread further along highways and interurban transport routes and by airplane. HIV has been, and in Asia is becoming, the best known beneficiary of this dynamic, but many other diseases, such as dengue, stand to benefit. The frequency of the most severe form, dengue hemorrhagic fever, which is thought to occur when a person is sequentially infected by two types of dengue virus, is increasing as different dengue viruses have extended their range and now overlap (25). Dengue hemorrhagic fever is now common in some cities in Asia, where the high prevalence of infection is attributed to the proliferation of open containers needed for water storage (which also provide breeding grounds for the mosquito vector) as the population size exceeds the infrastructure (19). In urban environments, rain-filled tires or plastic bottles are often breeding grounds of choice for mosquito vectors. The resulting mosquito population boom is complemented by the high human population density in such situations, increasing the chances of stable transmission cycles between infected and susceptible persons. Even in industrialized countries, e.g., the United States, infections such as tuberculosis can spread through high-population density settings (e.g., day care centers or prisons) $(12,26-28)$.

Human behavior can have important effects on disease dissemination. The best known examples are sexually transmitted diseases, and the ways in which such human behavior as sex or intravenous drug use have contributed to the emergence of HIV are now well known. Other factors responsible for disease emergence are influenced by a variety of human actions, so human behavior in the broader sense is also very important. Motivating appropriate individual behavior and constructive action, both locally and in a larger scale, will be essential for controlling emerging infections. I ronically, as AIDS prevention efforts have demonstrated, human 


\section{Perspectives}

behavior remains one of the weakest links in our scientific knowledge.

\section{International Travel and Commerce}

The dissemination of HIV through travel has already been mentioned. In the past, an infection introduced into people in a geographically isolated area might, on occasion, be brought to a new place through travel, commerce, or war (8). Tradebetween Asia and Europe, perhaps beginning with the silk route and continuing with the Crusades, brought the rat and one of its infections, the bubonic plague, toE urope. Beginning in the 16th and 17th centuries, ships bringing slaves from West Africa to the New World also brought yellow fever and its mosquito vector, Aedes aegypti, to the new territories. Similarly, smallpox escaped its Old World origins to wreak new havoc in the New World. In the 19th century, cholera had similar opportunities to spread from its probable origin in the Ganges plain to the Middle East and, from there, to Europe and much of the remaining world. Each of these infections had once been localized and took advantage of opportunities to be carried to previously unfamil iar parts of the world.

Similar histories are being repeated today, but opportunities in recent years have become far richer and more numerous, reflecting the increasing volume, scope, and speed of traffic in an increasingly mobile world. Rats have carried hantaviruses virtually worldwide (29). Aedes albopictus (the Asian tiger mosquito) was introduced into the United States, Brazil, and parts of Africa in shipments of used tires from Asia (30). Since its introduction in 1982 , this mosquito has established itsel $f$ in at least 18 states of the United States and has acqui red local viruses including Eastern equine encephalomyel itis (31), a cause of serious disease. Another mosquitoborne disease, malaria, is one of the most frequently imported diseases in non-endemic-disease areas, and cases of "airport malaria" are occasionally identified.

A classic bacterial disease, cholera, recently entered both South America (for the first time this century) and Africa. Molecular typing shows the South American isolates to be of the current pandemicstrain (32), supporting the suggestion that the organism was introduced in contaminated bilge water from an Asian freighter (33). Other evidence indicates that cholera was only one of many organisms to travel in ballast water; dozens, perhaps hundreds, of species have been exchanged between distant places through this means of transport alone. New bacterial strains, such as the recently identified Vibrio cholerae 0139, or an epidemic strain of Neisseria meningitidis $(34,35)$ (also examples of microbial adaptation and change) have dis- seminated rapidly along routes of trade and travel, as have anti biotic-resistant bacteria $(5,36)$.

\section{Technology and Industry}

High-volume rapid movement characterizes not only travel, but also other industries in modern society. In operations, including food production, that process or use products of biological origin, modern production methods yield increased efficiency and reduced costs but can increase the chances of accidental contamination and amplify the effects of such contamination. The problem is further compounded by globalization, allowing the opportunity to introduce agents from far away. A pathogen present in some of the raw material may find its way into a large batch of final product, as happened with the contamination of hamburger meat by E. coli strains causing hemolytic uremic syndrome (37). In the United States the implicated E. coli strains are serotype O157:H7; additional serotypes have been identified in other countries. Bovine spongiform encephalopathy (BSE), which emerged in Britain within the last few years, was likely an interspecies transfer of scrapie from sheep to cattle (38) that occurred when changes in rendering processes led to incomplete inactivation of scrapie agent in sheep byproducts fed to cattle (39).

The concentrating effects that occur with blood and tissue products have inadvertently disseminated infections unrecognized at the time, such as HIV and hepatitis B and C. Medical settings arealso at the front line of exposure to new diseases, and a number of infections, including many emerging infections, have spread nosocomially in health care settings (Table 2). Among the numerous examples, in the outbreaks of E bola fever in Africa many of the secondary cases were hospital acquired, most transmitted to other patients through contaminated hypodermic apparatus, and some to the health care staff by contact. Transmission of Lassa fever to health care workers has also been documented.

On the positiveside, advances in diagnostic technology can also lead to new recognition of agents that are al ready widespread. When such agents are newly recognized, they may at first often be labeled, in some cases incorrectly, as emerging infections. Human herpesvirus 6 (H HV-6) was identified only a few years ago, but the virus appears to be extremely widespread (40) and has recently been implicated as the cause of roseola (exanthem subitum), a very common chil dhood disease (41). Because roseola has been known since at least 1910, HHV-6 is likely to have been common for decades and probably much longer. Another recent example is the bacterium Helicobacter pylori, a probable cause of gastric ulcers $(42)$ and some cancers $(43,44)$. We have lived with these diseases for a long time without knowing 


\section{Perspectives}

their cause. Recognition of the agent is often advantageous, offering new promise of controlling a previously intractable disease, such as treating gastric ulcers with specific antimicrobial therapy.

\section{Microbial Adaptation and Change}

Microbes, like all other living things, are constantly evolving. The emergence of antibiotic-resistant bacteria as a result of the ubiquity of antimicrobials in the environment is an evolutionary lesson on microbial adaptation, as well as a demonstration of the power of natural selection. Selection for antibiotic-resistant bacteria $(5,36)$ and drug-resistant parasites has become frequent, driven by the wideand sometimes inappropriateuse of antimicrobial drugs in a variety of applications $(27,45,46)$. Pathogens can also acquire new antibiotic resistance genes from other, often nonpathogenic, species in the environment (36), selected or perhaps even driven by the selection pressure of antibiotics.

Many viruses show a high mutation rateand can rapidly evolve to yield new variants (47). A dassic exampleis influenza (48). Regular annual epidemics are caused by "antigenic drift" in a previously circulating influenza strain. A changein an antigenic site of a surface protein, usually the hemagglutinin $(\mathrm{H})$ protein, allows the new variant to reinfect pre viously infected persons becausethealtered antigen is not immediately recognized by the immune system.

On rare occasions, perhaps more often with nonviral pathogens than with viruses (49), the evolution of a new variant may result in a new expression of disease. The epi demic of Brazil ian purpuric fever in 1990, associated with a newly emerged clonal variant of Hemophilus influenzae, biogroup aegyptius, may fall into this category. It is possible, but not yet clear, that some recently described manifestations of disease by group A Streptococcus, such as rapidly invasive infection or necrotizing fasciitis, may also fall into this category.

\section{Breakdown of Public Health Measures and Deficiencies in Public Health Infrastructure}

Classical public health and sanitation measures have long served to minimize dissemination and human exposure to many pathogens spread by traditional routes such as water or preventable by immunization or vector control. The pathogens themselves often still remain, albeit in reduced numbers, in reservoir hosts or in the environment, or in small pockets of infection and, therefore, are often able to take advantage of the opportunity to reemerge if there are breakdowns in preventive measures.

Reemerging diseases are those, like cholera, that wereonce decreasing but are now rapidly increasing again. These are often conventionally understood and well recognized public health threats for which (in most cases) previously active public health measures had been allowed to lapse, a situation that unfortunately now applies all too often in both devel oping countries and the inner cities of the industrialized world. The appearance of reemerging diseases may, therefore, often be a sign of the breakdown of public health measures and should be a warning against complacency in the war against infectious di seases.

Cholera, for example, has recently been raging in South America (for thefirst timein this century) (50) and Africa. The rapid spread of cholera in South America may have been abetted by recent reductions in chlorine levels used to treat water supplies (34). The success of cholera and other enteric diseases is often due to the lack of a reliable water supply. These problems are more severe in developing countries, but are not confined to these areas. The U.S. outbreak of waterborne Cryptosporidium infection in Milwaukee, Wisconsin, in the spring of 1993, with over 400,000 estimated cases, was in part due to a nonfunctioning water filtration plant (51); similar deficiencies in water purification have been found in other cities in the United States (52).

\section{For our Future}

In his accompanying article, Dr. David Satcher discusses the history of infectious diseases and the many infections that, from the dawn of history tothe present, have traveled with the caravans and followed the invading armies. The history of infectious diseases has been a history of microbes on the march, often in our wake, and of microbes that have taken advantage of the rich opportunities offered them to thrive, prosper, and spread. And yet the historical processes that have given riseto theemergence of "new" infections throughout history continue today with unabated force; in fact, they are accelerating, because the conditions of modern life ensurethat thefactors responsible for diseaseemergence are more prevalent than ever before. Speed of travel and global reach are further borne out by studies modeling the spread of influenza epidemics (53) and HIV $(54,55)$.

Humans are not powerless, however, against this relentless march of mi crobes. Knowledge of the factors underlying disease emergence can help focus resources on the key situations and areas worldwide $(3,4)$ and devel op more effective prevention strategies. If we are to protect ourselves against emerging diseases, the essential first step is effective global 


\section{Perspectives}

disease surveillance to give early warning of emerging infections $(3,12,13,56)$. This must be tied to incentives, such as national development, and eventually be backed by a system for an appropriate rapid response. World surveillance capabilities are critically deficient $(12,56,57)$. Efforts, such as the CDC plan (13), now under way in the United States and internationally to remedy this situation are the essential first steps and deserve strong support. Research, both basic and applied, will also be vital .

\section{ThisJ ournal and the "Perspectives" Section}

Early warning of emerging and reemerging infections depends on the ability to identify the unusual as early as possible. Information is, ther efore, essential. Hence this journal, which is intended as a peer-reviewed forum for the discussion of concepts and examples relevant to emerging infectious diseases and their causes, and to provide a channel for field reports and observations on emerging infections. The "Perspectives" section will provide general overviews dealing with factors in disease emergence, conceptual syntheses of information, approaches for studying or predicting emerging infections, and analyses that shed light on how and why infections emerge, and how they may be anticipated and prevented. Submissions for this section are warmly invited. In coming issues, Perspectives will deal in greater detail with many of thefactors discussed in this overview article, and with ways to dissect steps in the emergence process. Discussion of technologies that are broadly applicable to the identification or control of emerging diseases are also appropriate for this section. Case studies are welcome if they are used to develop broader lessons.

\section{Acknowledgments}

I thank Dr. J ohn La Montagne, NIAID, for helpful discussions. Supported by NIH grant RR 03121 (from CMP), US DHHS.

Dr. Morse, "Perspectives" section editor of this journal, is assistant professor of virology at The Rockefeller University, New York, N.Y. He chaired the NIH Conference on Emerging Viruses (May 1989) and was a member of the committeeon Emerging Microbial Threats to Health (and chaired its Task Force on Viruses), convened by the Institute of Medicine, National Academy of Sciences (ref. 12).

\section{References}

1. Morse SS, Schluederberg A. Emerging viruses: the evolution of viruses and viral diseases. J I nfect Dis 1990;162:1-7.
2. MorseSS. Examining the origins of emerging viruses. In: MorseSS, ed. Emerging viruses. New York: Oxford University Press, 1993:10-28.

3. MorseSS. Regulating viral traffic. Issues Sci Technol 1990;7:81-4.

4. Morse SS. Emerging viruses: defining the rules for viral traffic. Perspect Biol Med 1991;34:387-409.

5. Soares $S$, Kristinsson KG, Musser J M, Tomasz A. Evidence for the introduction of a multiresistant clone of serotype 6B Streptococcus pneumoniae from Spain to I celand in thelate 1980s. J I nfect Dis 1993;168:15863.

6. Rogers DJ , Packer MJ . Vector-bornediseases, models, and gl obal change. Lancet 1993;342:1282-4.

7. Fiennes RW. Zoonoses and the origins and ecology of human disease. London: Academic Press, 1978.

8. McNeill WH. Plagues and peoples. New York: Anchor Press/ Doubleday, 1976.

9. Myers G, Macl nnes K, Korber B. The emergence of simian/human immunodeficiency viruses. AIDS Res Hum Retroviruses 1992;8:373-86.

10. Allan J S, Short M, Taylor ME, et al. Species-specific diversity among simian immunodeficiency viruses from African green monkeys. J Virol 1991;65:2816-28.

11. Gao F, Yue L, White AT, et al. Human infection by genetically diverse SIVSM-related HIV-2 in West Africa. Nature 1992;358:495-9.

12. Institute of Medicine. Emerging infections: Microbial threats to health in the United States (Lederberg J , Shope RE, Oaks SC J r, eds). Washington, DC: National Academy Press, 1992.

13. Centers for Disease Control and Prevention. Addressing emerging infectious disease threats: a prevention strategy for the United States. Atlanta, Georgia: US Dept of Health and Human Services, Public Health Service, 1994

14. Barbour AG, Fish D. The biological and social phenomenon of Lyme disease. Science 1993;260:1610-6.

15. J ohnson KM. Emerging viruses in context: an overview of viral hemorrhagic fevers. In: Morse SS, ed. Emerging viruses. New York: Oxford University Press, 1993:46-7.

16. Webster RG, Bean WJ , Gorman OT, Chambers TM Kawaoka Y. Evolution and ecology of influenza A viruses. Microbiol Rev 1992;56:152-79.

17. Scholtissek C, Naylor E. Fish farming and influenza pandemics. Nature 1988;331:215.

18. World Health Organization. Geographical distribution of arthropod-borne diseases and their principal vectors. Geneva: World Health Organization (WHONBC/89.967), 1989:138-48.

19. Monath TP. Arthropod-borne viruses. In: Morse SS, ed. Emerging viruses. N ew York: Oxford University Press, 1993.

20. Levins R, E pstein PR, Wilson ME, Morse SS, Slooff R, Eckardt I. Hantavirus disease emerging. Lancet 1993;342:1292.

21. Le Guenno B, Camprasse MA, Guilbaut J C, Lanoux P, Hoen B. Hantavirus epidemic in Europe, 1993. Lancet 1994;343:114-5.

22. Rollin PE, Coudrier D, Sureau P. Hantavirus epidemic in E urope, 1993. Lancet 1994;343:115-6. 


\section{Perspectives}

23. Epstein, PR, Ford TE, Colwell RR. Marine ecosystems. Lancet 1993;342:1216-9.

24. United Nations. World urbanization prospects, 1990. New York: United Nations, 1991.

25. Gubler DJ, Trent DW. Emergence of epidemic dengue/dengue hemorrhagic fever as a public health problem in the Americas. Infectious Agents and Disease 1993;26:383-93.

26. Krause RM. The origin of plagues: old and new. Science 1992;257:1073-8.

27. Bloom BR, Murray CJ L. Tuberculosis: commentary on a reemergent killer. Science 1992;257:1055-64.

28. Hoge CW, Reichler MR, Dominguez EA, et al. An epidemic of pneumococcal disease in an overcrowded, inadequately ventilated jail. N Engl J Med 1994;331:643-8.

29. LeDuc J W, Childs J E, Glass GE. The hantaviruses, etiol ogic agents of hemorrhagic fever with renal syndrome: a possible cause of hypertension and chronic renal disease in the United States. Annu Rev Public Health 1992;13:79-98.

30. Centers for Disease Control and Prevention. Aedes albopictus introduction into continental Africa, 1991. MMWR 1991;40:836-8.

31. Centers for Disease Control and Prevention. Eastern equine encephalitis virus associated with Aedes albopictus-Florida, 1991. MMWR 1992;41:115, 121.

32. Wachsmuth IK, Evins GM, Fields PI, et al. The molecular epidemiology of cholera in Latin America. J Infect Dis 1993;167:621-6.

33. Anderson $\mathrm{C}$. Cholera epidemic traced to risk miscalculation [News]. Nature 1991;354:255.

34. Moore PS. M eningococcal meningitis in sub-Saharan Africa: a model for the epidemic process. Clin Infect Dis 1992;14:515-25.

35. Moore PS, Broome CV. Cerebrospinal meningitis epidemics. Sci Am 1994;271(5):38-45.

36. Davies J . Inactivation of antibiotics and the dissemination of resistance genes. Science 1994;264:375-82.

37. Centers for Disease Control and Prevention. Update: multistate outbreak of Escherichia coli O157:H7 infections from hamburgers-western United States, 1992-1993. MMWR 1993;42:258-63.

38. Morse SS. L ooking for a link. Nature 1990;344:297.

39. Wilesmith JW, Ryan JBM, Atkinson MJ. Bovine spongiform encephal opathy: epidemiological studies on the origin. Vet Rec 1991;128:199-203.

40. I noueN, Dambaugh TR, Pellett PE. Mol ecular biology of human herpesviruses 6A and 6B. I nfectious Agents and Disease 1993;26:343-60.
41. Yamanishi K, OkunoT, Shiraki K, et al. I dentification of human herpesvirus- 6 as a causal agent for exanthem subitum. Lancet 1988;i:1065-7.

42. Peterson WL. Helicobacter pylori and peptic ulcer disease. N Engl J Med 1991;324:1043-8.

43. Nomura A, Stemmermann GN, Chyou P-H, Kato I, Perez-Perez GI , Blaser MJ . Helicobacter pyl ori infection and gastric carcinoma among J apanese Americans in Hawaii. N Engl J Med 1991;325:1132-6.

44. Parsonnet J, Friedman GD, Vandersteen DP, et al. Helicobacter pylori infection and the risk of gastric carcinoma. N Engl J Med 1991;325:1127-31.

45. Cohen ML. Epidemiology of drug resistance: implications for a post-antimicrobial era. Science 1992;257:1050-5.

46. Neu HC. The crisis in antibiotic resistance. Science 1992;257:1064-72.

47. Domingo $E$, Holland $\mathrm{J} J$. Mutation rates and rapid evolution of RNA viruses. In: Morse SS, ed. The evolutionary biology of viruses. N ew York: Raven Press, 1994:161-84.

48. Kilbourne ED. The molecular epidemiology of influenza. J Infect Dis 1978;127:478-87.

49. Morse SS. Toward an evolutionary bi ology of viruses. In: Morse SS, ed. The evolutionary biology of viruses. New York: Raven Press, 1994:1-28.

50. Glass RI, Libel M, Brandling-Bennett AD. Epidemic cholera in the Americas. Science 1992;265:1524-5.

51. MacKenzie WR, Hoxie NJ , Proctor ME, et al. A massive outbreak in Milwaukee of Cryptosporidium infection transmitted through the water supply. N Engl J Med 1994;331:161-7.

52. Centers for Disease Control and Prevention. Assessment of inadequately filter ed public drinking waterWashington, D.C., December 1993. MMWR 1994;43:661-3.

53. Longini I M J r, Fine PE M, Thacker SB. Predicting the global spread of new infectious agents. Am J Epidemiol 1986;123:383-91.

54. Flahault A, Valler on AJ . HIV and travel, no rationale for restrictions. Lancet 1990;336:1197-8.

55. Flahault A, Valleron AJ . A method for assessing the global spread of HIV-1 infection based on air travel. Mathematical Population Studies 1992;3:161-71.

56. Henderson DA. Surveillance systems and intergovernmental cooperation. In: Morse SS, ed. Emerging viruses. New York: Oxford University Press, 1993:283-9.

57. Berkelman RL, Bryan RT, Osterholm MT, LeDucJ W, Hughes J M. Infectious disease surveillance: a crumbling foundation. Science 1994;264:368-70. 